\title{
PENGARUH MOTIVASI EKSTRINSIK DAN PRESTASI BELAJAR AKUNTANSI TERHADAP MINAT INVESTASI DAN KEPUTUSAN INVESTASI MAHASISWA FE PROGRAM STUDI AKUNTANSI UNESA
}

\author{
Nur Wahyuning Sulistyowati, Pascasarjana Unesa \\ laurafredikson@yahoo.co.id
}

\begin{abstract}
ABSTRAK
Penelitian ini bertujuan untuk menganalisis pengaruh motivasi ekstrinsik dan prestasi belajar akuntansi terhadap minat investasi dan keputusan investasi mahasiswa. Hasil penelitian menunjukkan bahwa secara langsung motivasi ekstrinsik berpengaruh signifikan terhadap prestasi belajar akuntansi. Prestasi belajar akuntansi tidak berpengaruh signifikan terhadap minat investasi. Motivasi ekstrinsik berpengaruh signifikan terhadap minat investasi. Minat investasi berpengaruh signifikan terhadap keputusan investasi. Prestasi belajar akuntansi berpengaruh signifikan terhadap keputusan investasi, dan motivasi ekstrinsik berpengaruh signifikan terhadap keputusan investasi. Sedangkan secara tidak langsung motivasi ekstrinsik mempunyai pengaruh signifikan terhadap keputusan investasi melalui minat investasi, sehingga minat investasi terbukti memediasi motivasi ekstrinsik terhadap keputusan investasi mahasiswa, dan prestasi belajar akuntansi mempunyai pengaruh signifikan terhadap keputusan investasi melalui minat investasi, sehingga minat investasi terbukti memediasi prestasi belajar akuntansi terhadap keputusan investasi mahasiswa. Temuan dalam penelitian ini adalah bahwa minat investasi berperan penting dalam keputusan investasi mahasiswa.
\end{abstract}

Kata Kunci : Motivasi Ekstrinsik, Prestasi Belajar, Minat, Keputusan Investasi.

\section{ABSTRACT}

This study aimed to analyze the effect of extrinsic motivation and academic achievement for investment interest and investment decisions study. The results showed that extrinsic motivation has direct significant effect on accounting learning achievement. Accounting learning achievement does not significantly influence the investment interest. Extrinsic motivation has significant effect on investment interest. investments Interest significantly influence investment decisions. accounting Learning achievement has significant effect on investment decisions, and extrinsic motivation significantly influence investment decisions. While extrinsic motivation indirectly has a significant influence on investment decisions through investment interest, so that the interest showed to mediate investment extrinsic motivation on student investment decisions, and learning achievement of accounting has a significant influence on investment decisions through investment interest, so that the investment interest shown to mediate the learning achievement of accounting student investment decisions. The findings in this study is that the investment interest plays an important role in investment decisions of students.

Keywords : Extrinsic Motivation, Achievement, Interest, Investment Decision. 


\section{PENDAHULUAN}

Investasi merupakan komitmen seseorang untuk menempatkan sejumlah dana pada saat ini dengan harapan untuk memperoleh keuntungan di masa yang akan datang. Total jumlah penduduk di Indonesia yang mencapai 240 juta orang dan keinginan warga berinvestasi baru sekitar satu juta setengah persen dari jumlah penduduk, dimana minat investasi masyarakat masih rendah jika dibandingkan dengan negara-negara di Asia Tenggara, seperti Singapura dan Malaysia. Penyebab rendahnya minat investasi masyarakat adalah masyarakat kurang mendapatkan pengetahuan, masyarakat pernah menjadi korban penipuan dari lembaga investasi ilegal yang banyak beroperasi di daerah, dan masyarakat belum banyak mengetahui keuntungan investasi, sehingga BEI akan terus berupaya melakukan sosialisasi ke daerah-daerah di Indonesia.

Surabaya merupakan salah satu wilayah yang dijadikan BEI untuk melakukan sosialisasi. Kepemilikan saham BEI masih didominasi oleh pihak asing $60 \%$ dan sisanya investor lokal. Salah satu upaya BEI untuk menjaring investor domestik yaitu dengan diadakannya "Investor Summit and Capital Market Expo" yang bertujuan menjaring investor di Surabaya karena pertumbuhan ekonomi di jawa timur cukup tinggi dan minat investasi mengalami peningkatan.

Minat investasi mahasiswa Fakultas Ekonomi Program Studi Akuntansi masih rendah dibuktikan dengan informasi mengenai kegiatan investasi 5\% didapat dari pengalaman pelaku investasi, banyaknya alumni jurusan akuntansi yang bekerja hanya sebagai pegawai atau karyawan, dengan kurikulum sebagai dasar penyelenggaraan Program Studi serta mata kuliah yang sudah ada sebagai bekal pengetahuan investasi. Dari fenomena lapangan tersebut peneliti melakukan studi pendahuluan, dimana dalam studi pendahuluan peneliti melakukan wawancara awal, tahun 2014 dengan Pembantu Dekan Satu dan Ketua Jurusan Akuntansi Fakultas Ekonomi Universitas Negeri Surabaya, menyatakan bahwa untuk menumbuhkan minat investasi mahasiswa selain kurikulum sebagai dasar penyelenggaraan Program Studi dengan mata kuliah sebagai bekal pengetahuan investasi. Maka untuk menumbuhkan minat investasi mahasiswa lembaga juga telah melakukan berbagai upaya.

Upaya lembaga untuk menumbuhkan minat investasi mahasiswa diantaranya lembaga telah menjalin kerja sama dengan Bursa Berjangka, diadakannya seminar oleh jurusan terkait dengan investasi, Company Visit, dan kuliah tamu dengan mendatangkan praktisi sebagai dosen. Secara tidak langsung sebenarnya mahasiswa tidak perlu takut untuk terjun ke dunia investasi karena sudah memiliki bekal pengetahuan investasi. Selain wawancara ke beberapa dosen peneliti juga melakukan wawancara bebas ke beberapa mahasiswa akuntansi untuk memperoleh informasi langsung terkait dengan kegiatan penelitian. Fenomena di lapangan yaitu Kurikulum Fakultas Ekonomi Program Studi Akuntansi dengan mata kuliah yang sudah sesuai serta berbagai upaya lembaga dalam menumbuhkan minat investasi mahasiswa untuk berinvestasi merupakan salah satu faktor pendorong pertumbuhan ekonomi.

Peluang bagi para mahasiswa untuk memulai berinvestasi di usia muda. Reksa dana merupakan pilihan paling sederhana bagi investor pemula yang tidak punya banyak modal. Untuk investasi di logam mulia seperti emas, logam mulia lebih cocok sebagai jaminan ketika terjadi inflasi atau ketika kondisi ekonomi 
sedang memburuk. Jenis investasi lain yang bisa digunakan para anak muda adalah di sektor riil atau wirausaha karena tidak terlalu banyak memakan belanja modal seperti jasa atau perdagangan. Hampir semua pengusaha sukses memulai usahanya dengan investasi di sektor riil kecil-kecilan, seperti distributor pulsa misalnya yang perputaran uangnya tinggi, tapi inventorinya tidak perlu terlalu besar.

Reksa dana sebagai produk investasi yang paling tepat bagi mahasiswa karena reksa dana adalah wadah dan pola pengelolaan dana/ modal bagi sekumpulan investor untuk berinvestasi dalam instrumen-instrumen investasi yang tersedia di pasar dengan cara membeli unit penyertaan reksa dana. Dana ini kemudian dikelola oleh Manajer Investasi (MI) ke dalam portofolio investasi, baik berupa saham, obligasi, pasar uang ataupun efek/ sekuriti lainnya.

Motivasi merupakan serangkaian usaha untuk menyediakan kondisi tertentu, sehingga seseorang mau dan ingin melakukan sesuatu dan apabila tidak suka maka akan meniadakan rasa tidak suka tersebut. Motivasi belajar dikatakan ekstrinsik bila anak didik menempatkan tujuan belajarnya di luar faktor-faktor situasi belajar. Misalnya untuk mencapai angka tinggi, diploma, gelar, kehormatan, dan sebagainya.

Motivasi harus dilihat sebagai sebuah konsep relasional, bukan selain sebagai yang berada dalam diri individu (Ahl, 2006). Motivasi ekstrinsik adalah motivasi yang disebabkan oleh faktor-faktor dari luar situasi belajar, seperti : angka, kredit, ijazah, tingkatan, hadiah, medali, pertentangan, dan persaingan, yang bersifat negatif ialah sarkasme, ejekan (ridicule), dan hukuman (Hamalik, 2005). Mahasiswa yang mendapatkan motivasi ekstrinsik secara tidak langsung akan memiliki prestasi belajar akuntansi yang bagus karena mahasiswa mendapatkan motivasi dari luar dirinya untuk bisa meningkatkan prestasi belajar akuntansinya yaitu motivasi ekstrinsik, maka motivasi ekstrinsik berpengaruh terhadap prestasi belajar akuntansi.

Akuntansi adalah seni pencatatan, penggolongan, dan pengikhtisaran dengan cara tertentu dalam ukuran moneter, transaksi, dan kejadian-kejadian yang umumnya bersifat keuangan termasuk menafsirkan hasilnya (Harahap, 2003). Prestasi belajar sebagai tingkat keberhasilan siswa dalam mencapai tujuan yang ditetapkan dalam sebuah program (Syah, 2005). Prestasi merupakan hasil yang dicapai seseorang ketika mengerjakan tugas atau kegiatan tertentu (Tu'u, 2004). Prestasi belajar akuntansi adalah hasil belajar yang dicapai mahasiswa dalam proses belajar setelah menempuh seluruh mata kuliah pada Program Studi S1 Pendidikan Akuntansi, S1 Akuntansi, dan D3 Akuntansi Universitas Negeri Surabaya yang diprogram dalam semester yang telah diselesaikan diukur dengan nilai IPK. Prestasi belajar akuntansi mahasiswa Fakultas Ekonomi Program Studi Akuntansi Universitas Negeri Surabaya 3\% memuaskan, 89\% sangat memuaskan, $7 \%$ cumlaude. Dengan demikian prestasi belajar akuntansi mahasiswa tergolong sangat baik atau tinggi.

Minat investasi adalah keinginan, kecenderungan, ketertarikan atau dorongan yang kuat untuk melakukan kegiatan investasi disertai dengan perasaan senang dengan menanamkan modal satu atau lebih aktiva yang dimiliki di masa sekarang dengan harapan mendapatkan keuntungan di masa yang akan datang. Mahasiswa yang memiliki prestasi belajar akuntansi yang baik, secara tidak langsung mahasiswa tersebut akan memiliki pengetahuan mengenai materi 
keuangan dan investasi. Kegiatan mahasiswa 30\% berorganisasi, 32\% bekerja. Informasi mengenai investasi mahasiswa dapatkan 54\% dari perguruan tinggi (perkuliahan, buku, seminar, company visit), 13\% dari pribadi (keluarga, teman, tetangga), $21 \%$ dari media masa (Koran, majalah, TV), 7\% dari pelatihan investasi dan bursa saham. Minat investasi diukur dengan lima indikator yaitu: (1) ucapan dengan nilai rata-rata 3,009 tanggapan responden berkategori tinggi, (2) tindakan dengan nilai rata-rata 2,780 tanggapan responden berkategori sedang, (3) menjawab pertanyaan dengan nilai rata-rata 2,769 tanggapan responden berkategori sedang, (4) mengikuti aktivitas pada dunia yang diminati dengan nilai rata-rata 2,832 tanggapan responden berkategori sedang, (5) serius tidaknya dalam mengikuti aktivitas dengan nilai rata-rata 2,760 tanggapan responden berkategori sedang. Dengan demikian minat investasi mahasiswa masih tergolong sedang.

Latar belakang keluarga memainkan peran penting, baik melalui dampaknya terhadap prestasi pendidikan awal dan sikap untuk tugas sekolah, yang pada gilirannya mempengaruhi jenis sekunder-sekolah yang didatangi dan pencapaian kualifikasi pendidikan, dan ibu terdidik meningkatkan karir putri mereka dengan harapan atau memberikan teladan yang sukses (Kuh, et al., 1997). Kinerja akademik unggul perempuan memainkan peran besar dalam memproduksi kesenjangan gender di perguruan tinggi, tetapi efek ini tetap laten sampai setelah transisi ke perguruan tinggi. Keuntungan terbesar perempuan di perguruan tinggi sebagai penyelesaian dalam keluarga dengan ayah berpendidikan rendah (Buchmann \& DiPrete, 2006).

Karakteristik anak serta orang-orang dari orang tuanya adalah penentu utama pencapaian pendidikan. Dan karakteristik dari kakek-nenek di kerangka sesuatu yang belum pernah dilakukan dalam penelitian sebelumnya. Hubungan yang kuat antara ibu dan anak perempuan, serta antara ayah dan anak (Balsmeier \& Peters, 2009). Manfaat informasi keuangan tidak berpengaruh pada niat investasi; Norma subyektif positif mempengaruhi niat investasi; Norma subyektif berpengaruh positif terhadap revisi keyakinan; manfaat informasi akuntansi berpengaruh positif terhadap persepsi risiko sistematis; revisi keyakinan positif mempengaruhi niat investasi, dan persepsi risiko sistematis berpengaruh negatif terhadap niat investasi (Septyanto \& Adhikara, 2013).

Ekspektasi kinerja dan ekspektasi usaha dan faktor sosial berpengaruh positif signifikan terhadap minat pemanfaatan sistem informasi. Kondisi-kondisi yang memfasilitasi pemakai berpengaruh positif signifikan terhadap penggunaan sistem informasi dan minat pemanfaatan sistem informasi tidak berpengaruh terhadap penggunaan sistem informasi (Handayani, 2005). Persepsi dan motivasi memiliki pengaruh terhadap minat mahasiwa Jurusan Akuntansi Fakultas Ekonomi Universitas Brawijaya berkarir di bidang Perpajakan (Trisnawati, 2013).

Perilaku seseorang ditentukan oleh suatu intensi, yang merupakan fungsi dari tingkah laku terhadap perilaku norma subjektif. Intensi mampu memprediksi perilaku dengan sangat baik. Intensi merupakan representasi kognitif dari kesiapan seseorang untuk berperilaku, yang merupakan awal terbentuknya perilaku seseorang Theory of Reasoned Action (Ajzen, 1985). Untuk menumbuhkan minat investasi pada mahasiswa diperlukan motivasi ekstrinsik sebagai pendorong dari luar selain motivasi yang terdapat dalam diri mahasiswa itu sendiri. 
Investasi pada hakikatnya merupakan penempatan sejumlah dana dengan harapan untuk memperoleh keuntungan di masa mendatang (Halim, 2005). Investasi adalah menempatkan uang atau dana dengan harapan untuk memperoleh tambahan atau keuntungan tertentu atas uang atau dana tersebut (Ahmad, 2004). Investasi adalah komitmen atas sejumlah dana atau sumber daya lainnya yang dilakukan pada saat ini dengan tujuan memperoleh sejumlah keuntungan di masa yang akan datang (Tandelilin, 2001). Investasi adalah komitmen penempatan sejumlah dana pada saat ini dengan tujuan memperoleh keuntungan di masa yang akan datang. Sedangkan keputusan investasi adalah suatu tindakan yang dilakukan seorang individu untuk menentukan suatu pilihan dari dua atau lebih alternatif setelah dilakukan berbagai proses identifikasi hingga terbentuknya kesimpulan yaitu keputusan untuk berinvestasi.

Manajemen laba yang sebagian besar dilihat sebagai penargetan pihak eksternalitas perusahaan, juga dapat mempengaruhi keputusan internal (Stubben, 2008). Risiko investasi dan produk islamik atribut efek positif pada minat masyarakat untuk berinvestasi (Yuliati, 2011). Pengetahuan akuntansi dan jiwa kewirausahaan berpengaruh positif dan signifikan terhadap penggunaan informasi akuntansi dalam pembuatan keputusan investasi (Krisanti, 2012). Investor dalam proses pengambilan keputusan investasi mempertimbangkan informasi akuntansi, akan tetapi, faktor psikologi investor yang tercermin sebagai sinyal pribadi lebih mendominasi. Hasil analisis empirik menunjukkan bahwa pengaruh informasi akuntansi terhadap nilai-nilai pasar adalah tidak konsisten, namun investor menyatakan bahwa informasi akuntansi yang disajikan oleh perusahaan tetap menjadi pertimbangan penting dalam proses pengambilan keputusan investasi. Sinyal pribadi lebih mendominasi investor sebagai pertimbangan dalam proses pengambilan keputusan investasi, sebab investor memiliki kecenderungan psikologis untuk lebih mempertimbangkan sinyal pribadi dibandingkan sinyal publik (Puspitaningtyas, 2013).

Informasi akuntansi sebagai nilai yang bermanfaat bagi investor ternyata tidak sepenuhnya dimanfaatkan oleh investor saham individual, khususnya investor yang menggunakan analisis teknikal dan analisis non fundamental lainnya dalam analisis saham mereka. Ketidakcanggihan investor dalam menganalisis informasi akuntansi (naive investor), turut mempengaruhi investor sehingga tidak menganalisis informasi akuntansi. Ketika informasi akuntansi tidak berpengaruh terhadap pengambilan keputusan investasi investor, no-effect hypothesis berlaku. Sedangkan sophisticated investor yang memiliki kecanggihan dalam menganalisis informasi akuntansi, mempertimbangkan informasi akuntansi dalam pengambilan keputusan investasi mereka. Ketika informasi akuntansi berpengaruh terhadap keputusan investasi investor, mechanistic hypothesis berlaku (Aprillianto, 2014).

Keputusan investasi sering dipengaruhi oleh perilaku herding, yang menghasilkan kinerja yang kurang (Caldwell \& Dolvin, 2012). Motivasi berpengaruh positif dan signifikan terhadap sikap, dan pengambilan keputusan dan sikap berpengaruh positif dan signifikan terhadap pengambilan keputusan mahasiswa dalam memilih perguruan tinggi swasta di Sulawesi Selatan (Jamaluddin, dkk, 2010). Keputusan untuk menampilkan tingkah laku tertentu adalah hasil dari proses rasional yang diarahkan pada suatu tujuan tertentu dan mengikuti urutan-urutan berfikir (Baron \& Byrne, 2004). Keputusan sebagai 
proses penelusuran masalah yang berawal dari latar belakang masalah, identifikasi masalah, hingga pada terbentuknya kesimpulan atau rekomendasi (Fahmi, 2006). Baru 38\% mahasiswa sudah melakukan kegiatan bisnis dan dagang, serta informasi mengenai kegiatan investasi 5\% didapat dari pengalaman pelaku investasi. Keputusan investasi diukur dengan tiga indikator yaitu: (1) takut pada risiko dengan nilai rata-rata 2,765 tanggapan responden berkategori sedang, (2) hati-hati pada risiko dengan nilai rata-rata 2,701 tanggapan responden berkategori sedang, (3) suka risiko dengan nilai rata-rata 2,944 tanggapan responden berkategori sedang. Dengan demikian keputusan investasi mahasiswa masih tergolong sedang.

\section{METODE PENELITIAN}

Populasi sasaran dalam penelitian ini adalah seluruh mahasiswa akuntansi dengan rincian sebagai berikut: program studi diploma akuntansi (D3) di semester enam, program studi S1 pendididkan akuntansi, dan program studi S1 akuntansi di semester delapan yaitu dengan total jumlah keseluruhan 232 mahasiswa. Sampel penelitian sebesar 147 mahasiswa, dengan teknik simple random sampling. Teknik pengumpulan data menggunakan metode angket, dokumentasi, dan wawancara dengan analisis data menggunakan Structural Equation Modeling $(S E M)$. Spesifikasi model antar variabel digambarkan pada gambar dibawah ini.

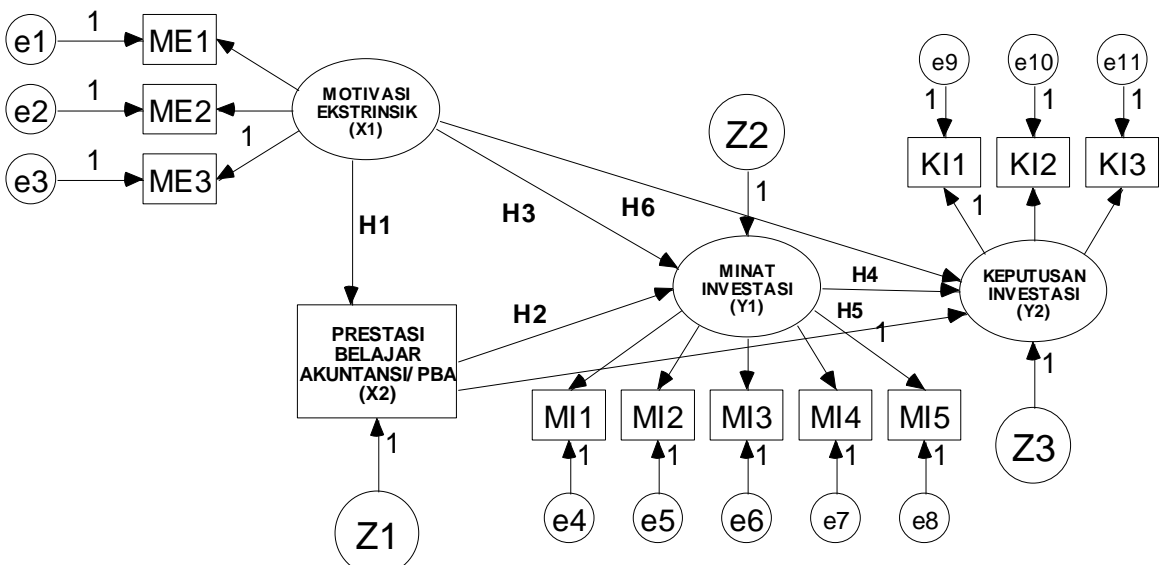

Gambar 1. Model Antar Variabel

\section{HASIL PENELITIAN DAN PEMBAHASAN}

Berdasarkan uji normalitas, secara univariate (per indikator) maupun multivariate nilai critical ratio berada pada interval $-2,58<\mathrm{CR}<2,58$. Dengan demikian seluruh data baik univariate maupun multivariate berdistribusi normal. Evaluasi outliers dapat dilakukan dengan analisis terhadap multivariate outliers. Sedangkan hasil nilai Z-score pada evaluasi outlier univariate dan multivariate seluruh indikator berada pada $-3,00 \leq Z$-score $\leq 3,00$ sehingga tidak ada outlier.

Pengujian hipotesis model penelitian ini dilakukan dengan menggunakan Structural Equation Modeling (SEM). Agar diperoleh model yang baik, dilakukan penilaian kesesuaian model atau goodness-of-fit. Pengujian ini dilakukan untuk 
mendapatkan kriteria model yang dapat diterima. Hasil uji Goodness Of Fit Index dengan nilai $\mathrm{X}^{2}$-chi-square 58,397, Significant Probability 0,123 $\geq 0,05$, CMIN/DF $1,242<2,00$, GFI $0,936 \geq 0,90$, AGFI $0,894 \geq 0,90$, TLI $0,967 \geq 0,95$, CFI $0,977 \geq$ 0,95 , RMSEA $0,041 \leq 0,08$. Berdasarkan uji goodness of fit disimpulkan model dapat diterima. Hasil pengujian hipotesis model persamaan struktural motivasi ekstrinsik, prestasi belajar akuntansi, minat investasi, dan keputusan investasi, dapat dilihat pada gambar 2 .

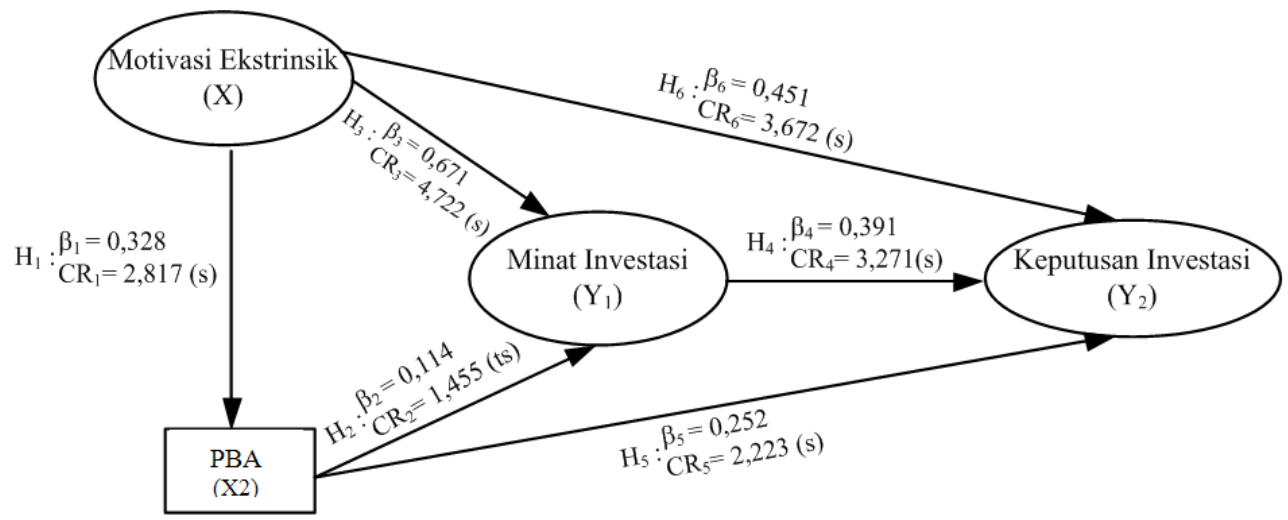

Gambar 2. Model Persamaan Struktural

Hasil pengujian hipotesis langsung : (1) Motivasi ekstrinsik berpengaruh signifikan terhadap prestasi belajar akuntansi dengan koefisien jalur bertanda positif sebesar 0,328 dan nilai C.R. sebesar 2,817 lebih besar dari 1,96. (2) Prestasi belajar akuntansi terbukti berpengaruh tidak signifikan terhadap minat investasi dengan koefisien jalur bertanda positif sebesar 0,114 dan nilai C.R. sebesar 1,455 lebih kecil dari 1,96. (3) Motivasi ekstrinsik berpengaruh signifikan terhadap minat investasi dengan koefisien jalur bertanda positif sebesar 0,671 dan nilai C.R. sebesar 4,722 lebih besar dari 1,96. (4) Minat investasi berpengaruh signifikan terhadap keputusan investasi dengan koefisien jalur bertanda positif sebesar 0,391 dan nilai C.R. sebesar 3,271 lebih besar dari 1,96. (5) Prestasi belajar akuntansi berpengaruh signifikan terhadap keputusan investasi dengan koefisien jalur bertanda positif sebesar 0,252 dan nilai C.R. sebesar 2,223 lebih besar dari 1,96. (6) Motivasi ekstrinsik berpengaruh signifikan terhadap keputusan investasi dengan koefisien jalur bertanda positif sebesar 0,451 dan nilai C.R. sebesar 3,672 lebih besar dari 1,96.

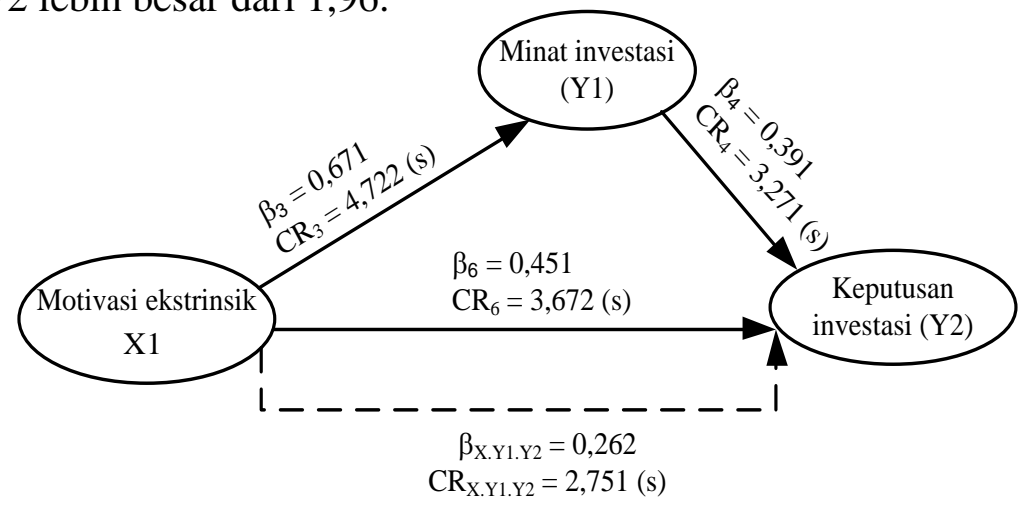

Gambar 3. Model Pengaruh Tidak Langsung Motivasi Ekstrinsik terhadap Keputusan Investasi melalui Minat Investasi 
Pengaruh motivasi ekstrinsik terhadap keputusan investasi melalui minat investasi sebesar 0,262 signifikan, sehingga minat investasi memediasi motivasi ekstrinsik terhadap keputusan investasi mahasiswa diterima.

Pengaruh Tidak Langsung Prestasi Belajar Akuntansi terhadap Keputusan Investasi melalui Minat Investasi.

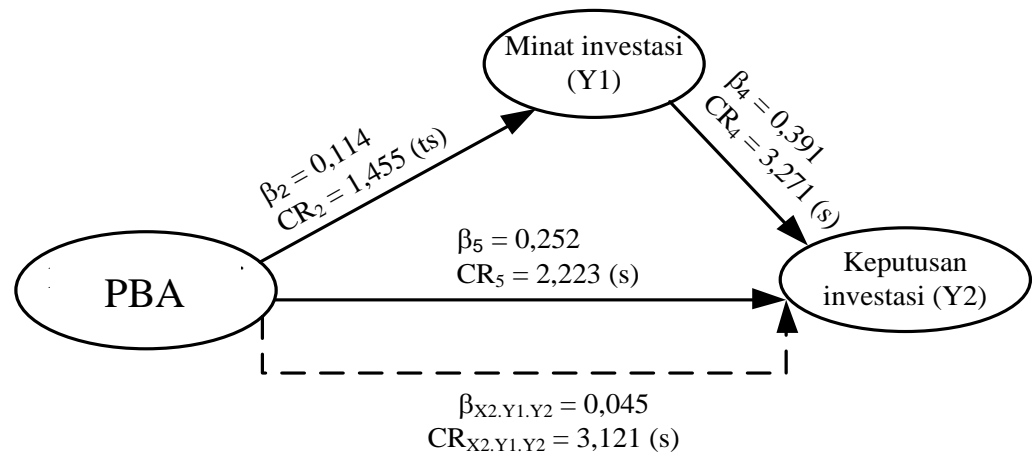

Gambar 4. Model Pengaruh Tidak Langsung PBA terhadap Keputusan Investasi dimediasi oleh Minat Investasi

Pengaruh prestasi belajar akuntansi terhadap keputusan investasi melalui minat investasi sebesar 0,045 signifikan, sehingga minat investasi memediasi prestasi belajar akuntansi terhadap keputusan investasi mahasiswa diterima.

Pengaruh Motivasi Ekstrinsik terhadap Prestasi Belajar Akuntansi sebesar 0,328 dimana motivasi ekstrinsik mempunyai pengaruh yang signifikan terhadap prestasi belajar akuntansi mahasiswa. Semakin baik motivasi ekstrinsik mahasiswa Program Studi Akuntansi Universitas Negeri Surabaya, maka akan semakin baik pula tingkat prestasi belajar akuntansinya.

Kuh et al. (1997) mengemukakan bahwa latar belakang keluarga memainkan peran penting, baik melalui dampaknya terhadap prestasi pendidikan awal dan sikap untuk tugas sekolah, yang pada gilirannya mempengaruhi jenis sekunder-sekolah yang didatangi dan pencapaian kualifikasi pendidikan, dan juga oleh ibu terdidik meningkatkan karir putri mereka harapan atau memberikan teladan yang sukses. Buchmann dan DiPrete (2006) menerangkan bahwa kinerja akademik unggul perempuan memainkan peran besar dalam memproduksi kesenjangan gender di perguruan tinggi, tetapi efek ini tetap laten sampai setelah transisi ke perguruan tinggi. Keuntungan terbesar perempuan di perguruan tinggi sebagai penyelesaian dalam keluarga dengan ayah berpendidikan rendah. Ahl (2006) menerangkan bahwa motivasi harus dilihat sebagai sebuah konsep relasional, bukan selain sebagai yang berada dalam diri individu.

Temuan pada variabel motivasi ekstrinsik yang terdapat pada indikator dua dan tiga yaitu adanya lingkungan yang baik dan adanya kegiatan yang menarik. Sebagian besar mahasiswa menyukai suasana yang flexible dan menyenangkan, mahasiswa lebih bersemangat untuk memahami materi investasi jika keadaan kelas nyaman, mahasiswa lebih bersemangat untuk memahami materi investasi jika keadaan kelas hidup dengan mahasiswa yang aktif, mahasiswa suka melakukan kegiatan di luar kuliah untuk mencari pengalaman, mahasiswa suka sekali diadakannya kuliah tamu dengan mendatangkan praktisi sebagai dosen. 
Temuan pada variabel prestasi belajar menunjukkan sebagian besar prestasi belajar akuntansi mahasiswa tergolong sangat baik atau tinggi.

Hamalik (2005) menerangkan bahwa motivasi ekstrinsik merupakan motivasi yang disebabkan oleh faktor-faktor dari luar situasi belajar, seperti : angka, kredit, ijazah, tingkatan, hadiah, medali, pertentangan dan persaingan, yang bersifat negatif ialah sarkasme, ejekan (ridicule), dan hukuman. Dengan demikian dapat disimpulkan bahwa motivasi ekstrinsik terbukti dapat memberikan sumbangan positif terhadap tercapainya prestasi belajar akuntansi mahasiswa yang tinggi dan terbukti dapat menjadi prediktor yang mempengaruhi prestasi belajar akuntansi pada mahasiswa.

Nilai koefisien jalur Belajar Akuntansi terhadap Minat Investasi sebesar 0,114 dan tidak terbukti mempunyai pengaruh yang signifikan terhadap minat investasi mahasiswa. Prestasi belajar akuntansi mahasiswa Fakultas Ekonomi Program Studi Akuntansi Universitas Negeri Surabaya tidak dapat mempengaruhi minat investasi mahasiswanya.

Penelitian ini bertentangan dengan penelitian sebelumnya yaitu hasil penelitian Septyanto dan Adhikara (2013) yang menyatakan bahwa manfaat informasi keuangan tidak berpengaruh pada niat investasi; Norma subyektif positif mempengaruhi niat investasi; Norma subyektif berpengaruh positif terhadap revisi keyakinan; manfaat informasi akuntansi berpengaruh positif terhadap persepsi risiko sistematis; revisi keyakinan positif mempengaruhi niat investasi, dan persepsi risiko sistematis berpengaruh negatif terhadap niat investasi.

Prestasi belajar akuntansi tidak berpengaruh signifikan terhadap minat investasi. Hasil temuan data dalam penelitian ini menunjukkan bahwa data deskripsi responden terdapat IPK mahasiswa berkategori cumlaude dan sangat memuaskan lebih tinggi dibandingkan kategori memuaska menunjukkan bahwa sebagian besar prestasi belajar akuntansi mahasiswa tergolong sangat baik atau tinggi. Didukung oleh temuan data responden bahwa informasi mengenai investasi didapat dari pengalaman sebagai pelaku investasi masih tergolong rendah.

Tidak berpengaruhnya prestasi belajar akuntansi terhadap minat mahasiswa dapat disebabkan oleh berbagai sebab diantaranya masih rendahnya mahasiswa dalam mengikuti aktivitas pada dunia yang diminati terbukti mahasiswa belum selalu ikut jika ada acara seminar yang berkaitan dengan investasi, mahasiswa belum suka berusaha sendiri untuk menyelesaikan tugastugasnya, mahasiswa belum sangat suka dengan kegiatan yang sesuai dengan latar belakang pendidikannya, dan serius tidaknya mahasiswa dalam mengikuti aktivitas juga masih rendah terbukti mahasiswa belum suka bertanya jika belum paham tentang materi investasi yang dijelaskan, mahasiswa belum memiliki komitmen menyediakan waktu setiap malam untuk belajar investasi, serta mahasiswa belum berantusias untuk memperhatikan jika ada penjelasan tentang investasi.

Hasil penelitian ini bertentangan dengan teori Tu'u (2004) yang menyatakan bahwa prestasi merupakan hasil yang dicapai seseorang ketika mengerjakan tugas atau kegiatan tertentu. Prestasi belajar adalah penguasaan pengetahuan atau keterampilan yang dikembangkan oleh mata pelajaran yang lazimnya ditunjukkan dengan nilai tes atau angka nilai yang diberikan guru. Jadi 
dengan prestasi belajar yang tinggi secara tidak langsung tingkat pemahaman pengetahuan tentang investasi pada khususnya juga akan tinggi pula, akan tetapi mahasiswa dengan prestasi belajar akuntansi yang tinggi belum terbukti memiliki minat investasi yang tinggi.

Motivasi ekstrinsik mempunyai pengaruh yang signifikan terhadap minat investasi mahasiswa dengan nilai koefisien jalur sebesar 0,671. Semakin baik motivasi ekstrinsik mahasiswa Fakultas Ekonomi Program Studi Akuntansi Universitas Negeri Surabaya, maka akan semakin baik pula tingkat minat investasi mahasiswanya.

Handayani (2005) mengemukakan bahwa ekspektasi kinerja dan ekspektasi usaha dan faktor sosial berpengaruh positif signifikan terhadap minat pemanfaatan sistem informasi. Kondisi-kondisi yang memfasilitasi pemakai berpengaruh positif signifikan terhadap penggunaan sistem informasi dan minat pemanfaatan sistem informasi tidak berpengaruh terhadap penggunaan sistem informasi. Trisnawati (2013) menerangkan bahwa persepsi dan motivasi memiliki pengaruh terhadap minat mahasiwa Jurusan Akuntansi Fakultas Ekonomi Universitas Brawijaya berkarir di bidang Perpajakan.

Motivasi ekstrinsik berpengaruh signifikan terhadap minat investasi mahasiswa didukung oleh temuan pada variabel motivasi ekstrinsik yang terdapat pada indikator dua dan tiga yaitu adanya lingkungan yang baik dan adanya kegiatan yang menarik. Sebagian besar mahasiswa menyukai suasana yang flexible dan menyenangkan, mahasiswa lebih bersemangat untuk memahami materi investasi jika keadaan kelas nyaman, mahasiswa lebih bersemangat untuk memahami materi investasi jika keadaan kelas hidup, mahasiswa suka melakukan kegiatan di luar kuliah untuk mencari pengalaman, mahasiswa suka sekali diadakannya kuliah tamu dengan mendatangkan praktisi sebagai dosen.

Didukung juga oleh temuan pada variabel minat investasi yang terdapat pada indikator satu, dua, dan lima yaitu ucapan, tindakan, dan serius tidaknya dalam mengikuti aktivitas. Hasil temuan menunjukkan bahwa mahasiswa menyatakan belajar investasi sangat perlu dan bermanfaat, mahasiswa berencana akan melakukan investasi untuk waktu yang akan datang, dan mahasiswa suka bertanya atau menanyakan jika belum paham tentang materi investasi yang dijelaskan sehingga lebih menyukai kelas yang hidup dan aktif.

Responden masih pada tingkat mahasiswa sehingga hasilnya tidak akan setinggi jika responden sudah pada tingkat pelaku investasi. Tanggapan responden pada indikator ucapan dan serius tidaknya dalam mengikuti aktivitas, hal ini dapat menunjukkan bahwa motivasi ekstrinsik berpengaruh terhadap minat investasi mahasiswa. Didukung oleh temuan data bahwa terdapat mahasiswa selain kuliah juga sudah bekerja; mahasiswa sudah melakukan kegiatan bisnis dan dagang; informasi mengenai investasi didapat mahasiswa dari Perguruan Tinggi melalui perkuliahan, buku, seminar, Company Visit; dan informasi mengenai investasi didapat dari pengalaman sebagai pelaku investasi.

Masih rendahnya responden sebagai pelaku investasi, akan tetapi dalam hal ini sudah dapat dijadikan harapan di masa yang akan datang untuk terjun di dunia investasi dengan bekal pengetahuan investasi yang sudah didapat mahasiswa dari pendidikan formal perkuliahan maupun non formal serta sudah terlihat bahwa mahasiswa telah memiliki minat investasi. 
Theory of Reasoned Action (Ajzen, 1985) menyatakan bahwa perilaku seseorang ditentukan oleh suatu intensi, yang merupakan fungsi dari tingkah laku terhadap perilaku norma subjektif. Intensi mampu memprediksi perilaku dengan sangat baik. Intensi merupakan representasi kognitif dari kesiapan seseorang untuk berperilaku, yang merupakan awal terbentuknya perilaku seseorang. Jadi dapat ditarik kesimpulan bahwa untuk menumbuhkan minat investasi pada mahasiswa diperlukan motivasi ekstrinsik sebagai pendorong dari luar selain motivasi yang terdapat dalam diri mahasiswa itu sendiri. Sehingga motivasi ekstrinsik berpengaruh langsung terhadap minat investasi mahasiswa.

Minat investasi berpengaruh signifikan terhadap keputusan investasi dengan nilai koefisien jalur sebesar 0,391. Minat investasi mahasiswa Fakultas Ekonomi Program Studi Akuntansi Universitas Negeri Surabaya mempengaruhi keputusan investasi mahasiswa.

Stubben (2008) mengemukakan bahwa manajemen laba yang sebagian besar dilihat sebagai penargetan pihak eksternalitas perusahaan, juga dapat mempengaruhi keputusan intern. Yuliati (2011) menyatakan bahwa risiko investasi dan produk islamik atribut efek positif pada minat masyarakat untuk berinvestasi.

Minat investasi berpengaruh signifikan terhadap keputusan investasi mahasiswa didukung oleh temuan variabel pada minat investasi dan yang terdapat pada indikator satu, dua, dan lima yaitu ucapan, tindakan, dan serius tidaknya dalam mengikuti aktivitas. Sebagian besar mahasiswa menyatakan belajar investasi sangat perlu dan bermanfaat, mahasiswa berencana akan melakukan investasi untuk waktu yang akan datang, dan mahasiswa suka bertanya atau menanyakan jika belum paham tentang materi investasi yang dijelaskan sehingga lebih menyukai kelas yang hidup dan aktif.

Temuan pada variabel keputusan investasi dan yang terdapat pada indikator satu dan dua yaitu takut pada risiko dan hati-hati pada risiko. Mahasiswa sangat suka dengan kegiatan yang sesuai dengan pengetahuan, mahasiswa selalu mempertimbangkan pada hal-hal yang kecil.

Responden masih pada tingkat mahasiswa sehingga hasilnya tidak akan setinggi jika responden sudah pada tingkat pelaku investasi. Terdapat mahasiswa telah kuliah dan bekerja; responden sudah melakukan kegiatan bisnis dan dagang; informasi mengenai investasi didapat dari Perguruan Tinggi melalui perkuliahan, buku, seminar, Company Visit, dan informasi mengenai investasi didapat dari pengalaman sebagai pelaku investasi. Masih rendahnya responden sebagai pelaku investasi, namun hal tersebut sudah dapat dijadikan harapan di masa yang akan datang untuk terjun di dunia investasi dengan bekal pengetahuan investasi yang sudah didapat mahasiswa dari pendidikan formal perkulihan maupun non formal.

Baron dan Byrne (2004) menyatakan bahwa keputusan untuk menampilkan tingkah laku tertentu adalah hasil dari proses rasional yang diarahkan pada suatu tujuan tertentu dan mengikuti urutan-urutan berfikir. Fahmi (2006) mendefinisikan keputusan sebagai proses penelusuran masalah yang berawal dari latar belakang masalah, identifikasi masalah, hingga pada terbentuknya kesimpulan atau rekomendasi. Jadi dapat ditarik kesimpulan bahwa minat investasi mahasiswa dapat mempengaruhi keputusan investasi mahasiswa setelah dilakukan berbagai proses identifikasi hingga terbentuknya kesimpulan untuk keputusan investasi. 
Prestasi belajar akuntansi mempunyai pengaruh yang signifikan terhadap keputusan investasi mahasiswa dengan nilai koefisien jalur sebesar 0,252. Semakin baik prestasi belajar akuntansi mahasiswa Fakultas Ekonomi Program Studi Akuntansi Universitas Negeri Surabaya, maka akan semakin baik pula tingkat keputusan investasi mahasiswanya.

Krisanti (2012) mengemukakan bahwa pengetahuan akuntansi dan jiwa kewirausahaan berpengaruh positif dan signifikan terhadap penggunaan informasi akuntansi dalam pembuatan keputusan investasi. Puspitaningtyas (2013) mengemukakan bahwa investor dalam proses pengambilan keputusan investasi mempertimbangkan informasi akuntansi. Akan tetapi, faktor psikologi investor yang tercermin sebagai sinyal pribadi lebih mendominasi. Jadi, meskipun hasil analisis empirik menunjukkan bahwa pengaruh informasi akuntansi terhadap nilai-nilai pasar adalah tidak konsisten, namun investor menyatakan bahwa informasi akuntansi yang disajikan oleh perusahaan tetap menjadi pertimbangan penting dalam proses pengambilan keputusan investasi. Sinyal pribadi lebih mendominasi investor sebagai pertimbangan dalam proses pengambilan keputusan investasi, sebab investor memiliki kecenderungan psikologis untuk lebih mempertimbangkan sinyal pribadi dibandingkan sinyal publik.

Aprillianto, dkk. (2014) menyatakan ketidakcanggihan investor dalam menganalisis informasi akuntansi (naive investor), turut mempengaruhi investor sehingga tidak menganalisis informasi akuntansi. Informasi akuntansi tidak berpengaruh terhadap pengambilan keputusan investasi investor, no-effect hypothesis berlaku. Sedangkan sophisticated investor yang memiliki kecanggihan dalam menganalisis informasi akuntansi, mempertimbangkan informasi akuntansi dalam pengambilan keputusan investasi mereka. Informasi akuntansi berpengaruh terhadap keputusan investasi investor, mechanistic hypothesis berlaku.

Sebagian besar prestasi belajar akuntansi mahasiswa tergolong sangat baik atau tinggi. Temuan pada variabel keputusan investasi yang terdapat pada indikator satu dan dua yaitu takut pada risiko dan hati-hati pada risiko. Mahasiswa sangat suka dengan kegiatan yang sesuai dengan pengetahuan, mahasiswa selalu mempertimbangkan pada hal-hal yang kecil.

Syah (2005) mendefinisikan prestasi belajar sebagai tingkat keberhasilan siswa dalam mencapai tujuan yang ditetapkan dalam sebuah program. Jadi dari beberapa uraian dapat ditarik kesimpulan bahwa perstasi belajar akuntansi berpengaruh siginifikan terhadap keputusan investasi.

Motivasi ekstrinsik berpengaruh signifikan terhadap keputusan investasi. Motivasi ekstrinsik mahasiswa Fakultas Ekonomi Program Studi Akuntansi Universitas Negeri Surabaya mempengaruhi keputusan investasi mahasiswa.

Caldwell dan Dolvin (2012) mengemukakan bahwa keputusan investasi sering dipengaruhi oleh perilaku herding, dimana menghasilkan kinerja yang kurang. Jamaluddin, dkk. (2010) mengemukakan motivasi berpengaruh positif dan signifikan terhadap sikap, dan pengambilan keputusan; serta sikap berpengaruh positif dan signifikan terhadap pengambilan keputusan mahasiswa dalam memilih perguruan tinggi swasta di Sulawesi Selatan.

Motivasi ekstrinsik berpengaruh signifikan terhadap keputusan investasi mahasiswa didukung oleh temuan pada variabel motivasi ekstrinsik yang terdapat pada indikator dua dan tiga yaitu adanya lingkungan yang baik dan adanya kegiatan yang menarik. Sebagian besar mahasiswa menyukai suasana yang 
flexible dan menyenangkan, mahasiswa lebih bersemangat untuk memahami materi investasi jika keadaan kelas nyaman, mahasiswa lebih bersemangat untuk memahami materi investasi jika keadaan kelas hidup (mahasiswa aktif), mahasiswa suka melakukan kegiatan di luar kuliah untuk mencari pengalaman, mahasiswa suka sekali diadakannya kuliah tamu dengan mendatangkan praktisi sebagai dosen.

Temuan pada variabel keputusan investasi yang terdapat pada indikator satu dan dua yaitu takut pada risiko dan hati-hati pada risiko. Mahasiswa sangat suka dengan kegiatan yang sesuai dengan pengetahuan, mahasiswa selalu mempertimbangkan pada hal-hal yang kecil.

Responden masih pada tingkat mahasiswa sehingga hasilnya tidak akan setinggi jika responden sudah pada tingkat pelaku investasi. Indikator adanya lingkungan yang baik berkategori tinggi, hal ini menunjukkan bahwa motivasi ekstrinsik berpengaruh terhadap keputusan investasi mahasiswa, mahasiswa selain kuliah juga sudah bekerja; mahasiswa sudah melakukan kegiatan bisnis dan dagang; informasi mengenai investasi didapat mahasiswa dari Perguruan Tinggi melalui perkuliahan, buku, seminar, Company Visit; dan informasi mengenai investasi didapat dari pengalaman sebagai pelaku investasi. Meskipun responden sebagai pelaku investasi masih tergolong rendah, namun sudah dapat dijadikan harapan di masa yang akan datang untuk terjun di dunia investasi dengan bekal pengetahuan investasi yang sudah didapat mahasiswa dari pendidikan formal perkuliahan maupun non formal.

Baron dan Byrne (2004) menyatakan bahwa keputusan untuk menampilkan tingkah laku tertentu adalah hasil dari proses rasional yang diarahkan pada suatu tujuan tertentu dan mengikuti urutan-urutan berfikir. Fahmi (2006) juga mendefinisikan keputusan sebagai proses penelusuran masalah yang berawal dari latar belakang masalah, identifikasi masalah, hingga pada terbentuknya kesimpulan atau rekomendasi. Jadi dapat ditarik kesimpulan bahwa motivasi berpengaruh signifikan terhadap keputusan investasi mahasiswa.

\section{SIMPULAN}

Berdasarkan analisis dan pembahasan yang telah dilakukan maka penelitian ini menyimpulkan beberapa hal diantaranya pengaruh langsung yaitu motivasi ekstrinsik mempengaruhi prestasi belajar akuntansi, prestasi belajar akuntansi tidak mempunyai pengaruh signifikan terhadap minat investasi, motivasi ekstrinsik mempengaruhi minat investasi, minat investasi mempengaruhi keputusan investasi, prestasi belajar akuntansi mempengaruhi keputusan investasi, dan motivasi ekstrinsik mempengaruhi keputusan investasi mahasiswa. Secara langsung prestasi belajar akuntansi mahasiswa tidak dapat mempengaruhi minat investasi mahasiswa, diantaranya disebabkan oleh masih rendahnya mahasiswa dalam mengikuti aktivitas pada dunia yang diminati terbukti mahasiswa belum selalu ikut jika ada acara seminar yang berkaitan dengan investasi, mahasiswa belum suka berusaha sendiri untuk menyelesaikan tugas-tugasnya, mahasiswa belum sangat suka dengan kegiatan yang sesuai dengan latar belakang pendidikannya, dan serius tidaknya mahasiswa dalam mengikuti aktivitas juga masih rendah terbukti mahasiswa belum suka bertanya jika belum paham tentang materi investasi yang dijelaskan, mahasiswa belum memiliki komitmen 
menyediakan waktu setiap malam untuk belajar investasi, serta mahasiswa belum berantusias untuk memperhatikan jika ada penjelasan tentang investasi.

Sedangkan pengaruh tidak langsung yaitu motivasi ekstrinsik mempunyai pengaruh signifikan terhadap keputusan investasi melalui minat investasi, sehingga minat investasi memediasi motivasi ekstrinsik terhadap keputusan investasi mahasiswa. Prestasi belajar akuntansi mempunyai pengaruh signifikan terhadap keputusan investasi melalui minat investasi, sehingga minat investasi memediasi prestasi belajar akuntansi terhadap keputusan investasi mahasiswa. Temuan dalam penelitian ini bahwa minat investasi berperan penting dalam keputusan investasi mahasiswa Fakultas Ekonomi Program Studi Akuntansi Universitas Negeri Surabaya.

\section{DAFTAR RUJUKAN}

Ahl, Helene, 2006. Motivation in adult education A problem solver or a Euphemism for direction and control?.The International Journal of Lifelong Education, 25 (5).

Ahmad, Kamaruddin, 2004. Dasar-Dasar Manajemen Investasi Dan Portofolio Edisi Revisi. Jakarta : PT Rineka Cipta.

Ajzen, I., 1985. From intentions to actions: A theory of planned behavior. In J.

Aprillianto, Bayu; Wulandari, Novi; Taufik Kurrohman, 2014. Perilaku Investor Saham Individual Dalam Pengambilan Keputusan Investasi: Studi Hermeneutika-Kritis. e-Journal Ekonomi Bisnis dan Akuntansi, 2014, Volume 1 (1) : 16-31.

Balsmeier \& Peters. 2009. Latar belakang keluarga atau Karakteristik Anak: Apa Menentukan SMA Sukses di Jerman?. Journal of Economics and Economic Education Research, Volume 10, Number 1, 2009.

Baron, Robert A \& Donn Byrne, 2004. Psikologi Sosial Jilid 1 (Edisi Ke Sepuluh). Jakarta : Erlangga.

Buchmann ,Claudia \& DiPrete, Thomas A., 2006. The Growing Female Advantage in College Completion: The Role of Family Background and Academic Achievement. American Sociological Review; Aug 2006; 71, 4; ProQuest Education Journals pg. 515.

Caldwell, Craig B. \& Dolvin, Steven D, 2012. Herding Behavior In Student Managed Investment Funds: Identification, Impact And Reduction. Journal of Economics and Economic Education Research, Volume 13, Number 2, 2012.

Fahmi, Irham, 2006. Analisis Investasi dalam Prespektif Ekonomi dan Politik. Bandung. PT Refika Aditama.

Halim, Abdul, 2005. Analisis Investasi. Jakarta : Salemba Empat.

Hamalik, Oemar, 2005. Kurikulum Dan Pembelajaran. Jakarta : PT Bumi Aksara. Handayani, Rini, 2005. Analisis Faktor-Faktor yang Mempengaruhi Minat Pemanfaatan Sistem Informasi dan Penggunaan Sistem Informasi (Studi Empiris Pada Perusahaan Manufaktur di Bursa Efek Jakarta). journals accounting petra.

Harahap, Sofyan Syafri, 2003. Teori Akuntansi Keuangan. Jakarta : PT Raja Grafindo Persada. 
Krisanti, 2012. Pengaruh Pengetahuan Akuntansi dan Jiwa Kewirausahaan Terhadap Penggunaan Informasi Akuntansi Dalam Pembuatan Keputusan Investasi. E-Jurnal Akuntansi Universitas Udayana. Vol. 1, No. 1 November 2012.

Kuh, Diana et al., 1997. The Influence of Education and Family Background on Women's Earning in Midlife : evidence from a British national birth cohort study. British Journal of Sociology of Education; Sep 1997; 18, 3; ProQuest Education Journals pg. 385.

Puspitaningtyas, Zarah, 2013. Perilaku Investor dalam Pengambilan Keputusan Investasi Di Pasar Modal. Prosiding Seminar Nasional \& Call for Paper Forum Manajemen Indonesia (FMI) ke-5. Istana Rakyat Kalbar \& Hotel Mercure Pontianak pada tanggal 23-24 Oktober 2013

Sawaji, Jamaluddin; Hamzah, Djabir; Taba, Idrus, 2010. Pengambilan Keputusan Mahasiswa dalam Memilih Perguruan Tinggi Swasta Di Sulawesi Selatan. E-Journal Program Pascasarjana Universitas Hasanuddin. Tahun 2011.

Septyanto, Dihin \& Adhikara, MF. Arrozi, 2013. Perilaku Investor Individu Dalam Pengambilan Keputusan Investasi Sekuritas Di Bursa Efek Indonesia (BEI). Jurnal Ekonomi. Vol. 4 No. 2 November 2013. Hal. 90101.

Syah, Muhibbin, 2005. Psikologi Pendidikan dengan Pendekatan Baru. Bandung : PT Remaja Rosdakarya.

Tandelilin, Eduardus, 2001. Analisis Investasi dan Manajemen Portofolio.Yogyakarta : BPFE.

Trisnawati, Mei K., 2013. Pengaruh Persepsi Dan Motivasi Terhadap Minat Mahasiswa Jurusan Akuntasi Fakultas Ekonomi Dan Bisnis Universitas Brawijaya Berkarir Di Bidang Perpajakan. Jurnal Ilmiah Mahasiswa FEB. Vol. 3 No. 2.

Tu'u, Tulus, 2004. Peran Disiplin pada Perilaku dan Prestasi Siswa. Jakarta : Grasindo.

Yuliati, 2011. Faktor-Faktor Yang Mempengaruhi Minat Masyarakat Berinvestasi Sukuk. Walisongo. Vol. 19 No. 1. Mei 2011. Hal. $103-126$. 